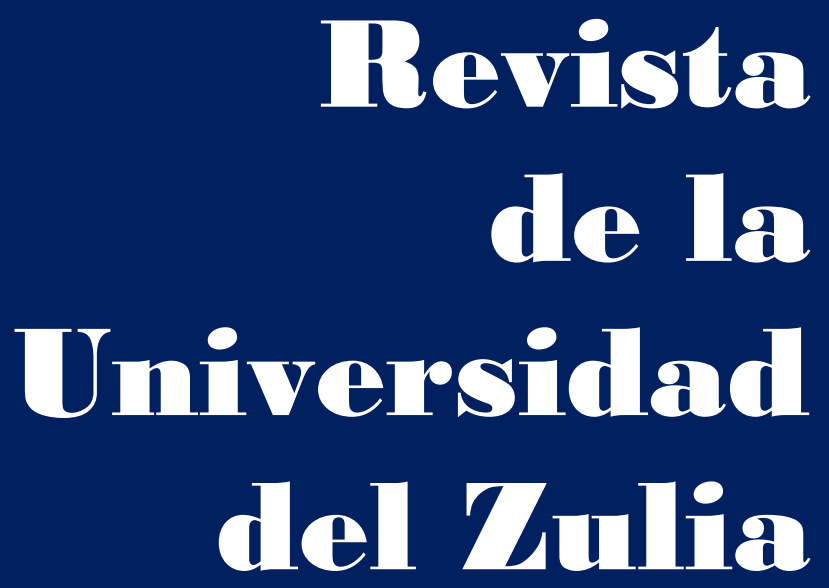

Fundada en 1947

por el Dr. Jesús Enrique Lossada

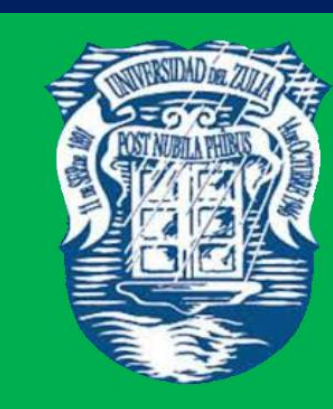

Ciencias del

Agrad,

Ingemiería

y Tecinología

\section{Aกัต 13 No $\mathbf{3 6}$} Enero - Abril 2022

Tercera Épaca

Maracailbo-Venezuela 


\title{
Assessment of the efficiency of using information modeling technology for buildings and structures as a construction security planning tool
}

\author{
Elen Bilonda Tregubova* \\ Ruben Kazaryan**
}

\begin{abstract}
Objective: presentation of an innovative method for the development of organizational and technological solutions, economically supported, that allow to provide an optimal response regarding the time and cost of construction production, the method of its use, the economic support for the application of this method in the development and implementation of the construction organization plan (COP) of industrial facilities. Methods: systems approach, statistical and comparative analysis, national and international developments in the field of construction production organization, economic and visual modeling, construction information modeling. Results: the tests of buildings and structures were analyzed in order to study the elements of the quality systems of BIM technologies in planning, security management of construction production. An algorithm for the operation of this model is presented for the development of a construction organization project (COP). Conclusions: Construction research shows that 4D Building Information Modeling (BIM) can improve the planning, control and management of security at a construction site.

KEY WORDS: 4D technology; economic and visual mathematical models of buildings and structures; security; construction organization project; mathematical models of building information; master plan.
\end{abstract}

*Moscow State University of Civil Engineering, 26 Yaroslavskoe shosse, Moscow, 129337, Russia, https://orcid.org/0000-0002-0955-0821. E-mail: lena.tregubova.99@inbox.ru

**Moscow State University of Civil Engineering, 26 Yaroslavskoe shosse, Moscow, 129337, Russia, https://orcid.org/0000-0003-0971-4301. E-mail: r.kazarian@mail.ru 


\section{Evaluación de la eficiencia del uso de tecnología de modelado de información para edificios y estructuras como herramienta de planificación de seguridad en la construcción}

RESUMEN

Objetivo: presentación de un método innovador para el desarrollo de soluciones organizativas y tecnológicas, sustentadas económicamente, que permitan brindar una respuesta óptima en cuanto al tiempo y costo de producción de la construcción, el método de su uso, la sustentación económica para la aplicación de este método en el desarrollo e implementación del plan de organización de la construcción (POC) de instalaciones industriales. Métodos: enfoque de sistemas, análisis estadístico y comparativo, desarrollos nacionales e internacionales en el campo de la organización de la producción de la construcción, modelado económico y visual, modelado de información de construcción. Resultados: se analizaron las pruebas de edificios y estructuras con el fin de estudiar los elementos de los sistemas de calidad de las tecnologías BIM en la planificación, gestión de seguridad de la producción de la construcción. Se presenta un algoritmo para el funcionamiento de este modelo para el desarrollo de un proyecto de organización de la construcción (POC). Conclusiones: la investigación en construcción muestra que el modelado de información de construcción 4D (BIM) puede mejorar la planificación, el control y la gestión de la seguridad en un sitio de construcción.

PALABRAS CLAVE: tecnología 4D; modelos matemáticos económicos y visuales de edificios y estructuras; seguridad; proyecto de organización de la construcción; modelos matemáticos de información de edificios; plan maestro.

\section{Introduction}

One of the main research instruments is Building Information Modeling (BIM). The concept of BIM technology and controls are considered in relation to construction safety. The use of 4D BIM opens up opportunities for the development of digital control systems that provide a solution to a complex of events in the construction production. As objects of research, industrial facilities were considered, the development of which was carried out in compliance with the current regulatory documents of the Russian Federation. The subject of the study is technologies and methods of developing COP for industrial facilities from the point of view of economic efficiency and feasibility, the use of 4D planning methods for the 
REVISTA DE LA UNIVERSIDAD DEL ZULIA. $3^{a}$ época. Año $13 \mathrm{~N}^{\circ}$ 36, 2022

Elen Bilonda Tregubova \& Ruben Kazaryan /// Assessment of the efficiency of using information... 305-322

DOI: http://dx.doi.org/10.46925//rdluz.36.20

purpose of modeling, management, as well as construction safety control. Study of the role and place of the construction organization project in the investment and construction process, the regulatory framework for the organization of construction production; analysis of modern foreign experience in the use of leading methods that are used to reduce the time and estimated cost of construction production, including project control, 3-4D-design, network planning method, mathematical modeling of in-line construction, visual planning of the organization of construction production, rationing, and also the estimate of the cost of labor.

Advanced information modeling (BIM) is a method that allows designing objects for various purposes in the information field, high-quality management of work carried out at each stage of the building's life cycle. This technology makes it possible to display in detail the internal and external views of the object using images, as well as to control construction equipment in automatic mode. BIM-modeling makes it possible to create architectural concepts, which, in their essence, are as close as possible to the capabilities of modern technologies, and also allows making a real time forecast of the probability of building objects with certain parameters in the process of preserving a real architectural idea (Adnan Enshassi et al, 2016; Aleksandrova, 2018; Akinci et al, 2002). The problem that is relevant for the design and organization of construction production is the consideration of variable factors in real time. BIM technologies provide accounting using modern innovative 4D modeling methods. Using of BIM for the subsequent operation of buildings and structures goes beyond the threedimensional spatial model and uses 4, 5, 6 dimensions. Each level provides the accumulation of new volumetric information corresponding to the level of the element base for measuring information by analogy with system quanta (Sulankivi, 2014; Sulankivi, 2015; Vitaliy et al, 2020). Thus, the developed 3D information model is the basis for 4 -,5 -, 6D-models and is the starting point for the development of working documentation, design and manufacture of building structures, creation of technical conditions, for economic assessment and organization of construction of buildings and structures (Fig.1).

$3 \mathrm{D}$ BIM is an integrated data model from which various interested parties, such as architects, design engineers, builders and project owners, can extract and enter information according to their needs. 3D BIM's visualization capabilities allow participants not only to see a building in three dimensions, but also to automatically update those views during the 
project lifecycle. 3D BIM helps participants more effectively manage their interdisciplinary collaboration in modeling and analyzing complex problems.

$4 \mathrm{D}$ BIM is a design method that considers a construction object not only in the space of the information field, but also in time. It is used for site planning activities. The fourth dimension of BIM allows participants to extract and visualize the progress of activities throughout the entire life cycle of a project. The use of 4D BIM technology can lead to better control over identification of conflicts or the complexity of changes occurring during the construction process.

5D BIM is an information model that also includes the cost of the project. It is used for budget tracking and expense analysis. The fifth dimension of BIM, related to 3D and 4D (time), allows participants to visualize the course of their activities and associated costs over time. The use of 5D BIM technology can result in greater accuracy and predictability in design estimates, changes in volume and material, equipment or labor.

6D BIM model gives complete information about the project. It is used to monitor the state of the building and allows effective management of the facility during construction, scheduled and routine repairs, reconstruction (Adnan Enshassi et al, 2016; Aleksandrova, 2018; Akinci et al, 2002; Bachurina et al, 2015; Churbanov et al, 2018; Sulankivi, 2014; Sulankivi, 2015; Vitaliy et al, 2020; Chulkov et al, 2020).

Nowadays, the attention to advanced technologies and methods of control over construction projects is increasing all over the world. For example, EVM is currently used in 58 countries, mainly in projects related to the construction of civil, transport, infrastructure, energy, oil and gas facilities. McGraw Hill Construction (Smart Market Report 2012: "The Business Value of BIM in North America: Multi-Year Trend Analysis and User Ratings (20072012)) provided a report that outlines the extent to which BIM is being applied. According to this data, the USA uses this technology for $71 \%$, and in the UK - 54\% (according to the NBS National BIM Report 2014). In 2014, in the EU countries, when placing orders for construction production, which are financed from the state budget, it was recommended to use a EVM. The area of potential applications is constantly expanding (Fig. 1). 

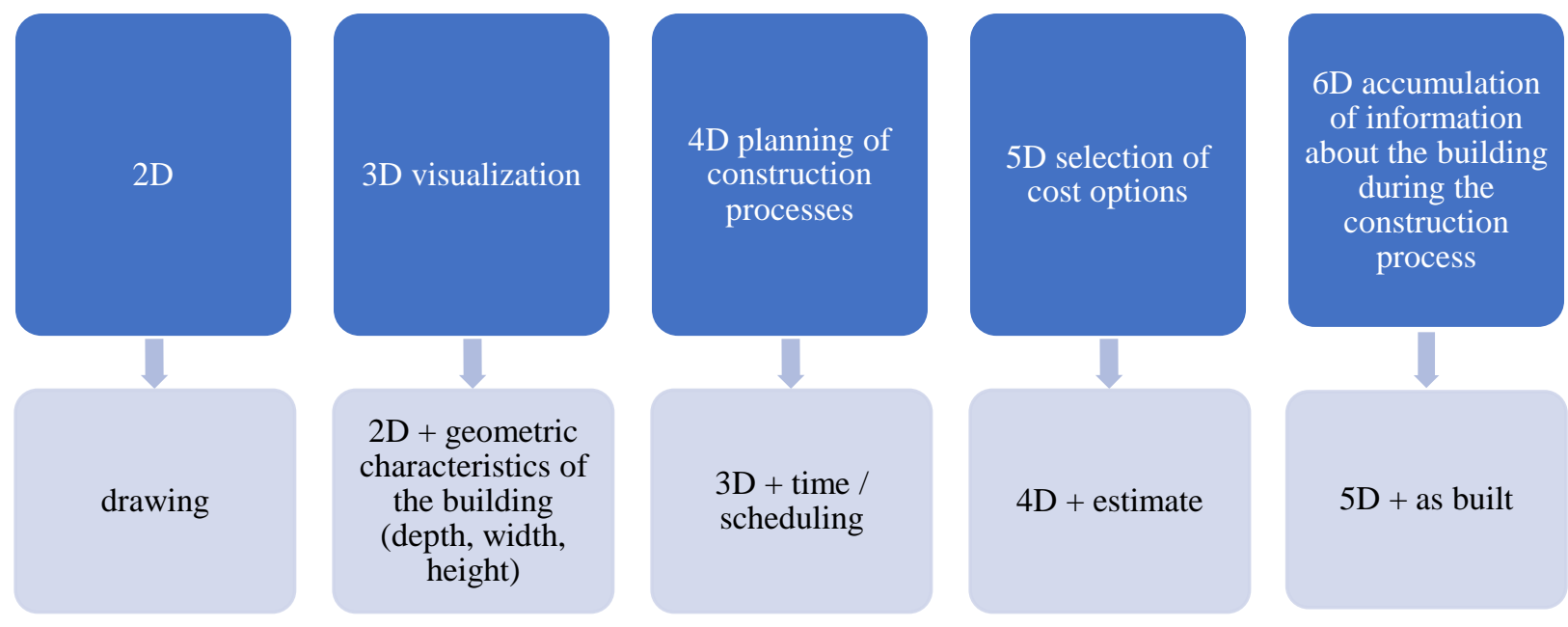

Figure 1. BIM cycle of buildings and structures

Before starting construction and installation work, it is necessary to prepare an operational business plan for the construction site, showing the main parameters for using the area of the site for construction. In this regard, the project is subject to systematic analysis in order to identify the dangers and risks that are associated with the organization, practical restructuring and the use of a certain construction plan, with subsequent elimination (if necessary), with the use of appropriate management tools. In the process of designing a master plan, the following basic elements of the organization should be considered:

1. Number and location of office and other premises required for personnel and warehouses;

2. Location of cranes, construction machines and equipment;

3. Location of the embankment;

4. Location of places for loading, unloading and storage of building materials, structures and prefabricated elements;

5. Traffic in the area of the construction site;

6. Entrances, ramps and transport routes, as well as their maintenance;

7. Collection, storage, removal and disposal of waste and materials that are harmful to the health and safety of workers;

8. Fire extinguishing;

9. Organization of special storage facilities using materials and substitutes that cause negative impact on the health and safety of workers. 
REVISTA DE LA UNIVERSIDAD DEL ZULIA. $3^{a}$ época. Año $13 \mathrm{~N}^{\circ}$ 36, 2022

Elen Bilonda Tregubova \& Ruben Kazaryan /// Assessment of the efficiency of using information... 305-322

DOI: http://dx.doi.org/10.46925//rdluz.36.20

The above issues are subject to precise control in full compliance with the elements of ISO-9000, ISO-14000 quality systems. The risks of accidents, fire hazards and other force majeure situations at the construction site must be minimized (Khoshnava et al, 2012; Korabelnikova et al, 2019; Lu Y. et al, 2021; Kazaryan, 2019; Kazaryan, 2020). With the traditional method of developing a construction plan, a 2D site layout plan is prepared, the purpose of which is to plan operations on the site and the necessary measures to maximize the efficiency of the planned work at all stages of construction. Nowadays, building information modeling (BIM) in the construction industry is seen as a tool that provides an opportunity to improve occupational safety. BIM can be used in the design, training and education on safety engineering, the formation of the initial requirements of the tasks to find the most optimal solution for the cost of the construction of the facility, taking into account the organizational and technical elements of planning, the investigation of accidents, as well as ensuring the safety of facilities and maintenance in full compliance with the requirements of ISO-9000 (Hartmann et al, 2007; Hiravennavar et al, 2020; International Labour OYce, 1985; Sulankivi, 2014).

\section{Methods}

The theoretical, methodological and informational basis of the study is international and domestic developments in the field of organization of construction production, visual modeling, BIM. The scientific basis of the work is the regulatory framework of the Russian Federation in the field of organization of construction production, studies by Russian and foreign authors. Literary analysis revealed that BIM technologies can be used to monitor and manage the safety of workers on a construction site and to combine safety with other construction planning processes. Turner Construction (Downey, 2012) has established a standard procedure to ensure compliance with safety standards. BIM specialists have developed a set of rules based on the Solibri Model Checker. This system is based on the application of the theory of project management, 3D modeling methods, in-line organization of construction, rationing and assessment of labor costs, scheduling and network planning, EVM. The solution to this problem entailed the use of methods of economic, statistical and comparative analysis. The Finnish Technical Research Center has developed an integrated structure for modeling the protection from force majeure situations. The introduction of 4D visualization, including the simulation of temporary protective structures and equipment 
REVISTA DE LA UNIVERSIDAD DEL ZULIA. $3^{a}$ época. Año $13 \mathrm{~N}^{\circ}$ 36, 2022

Elen Bilonda Tregubova \& Ruben Kazaryan /// Assessment of the efficiency of using information... 305-322

DOI: http://dx.doi.org/10.46925//rdluz.36.20

necessary to ensure the safe conduct of construction and installation works, multiplies the capitalization of the project (simulates the permanent installation of security equipment in a building during construction, operation and maintenance). The technological cycles for the introduction of best practices in joint planning procedures between the general contractor, designers and subcontractors are being improved. Thus, on the basis of research on the implementation of BIM technologies, intelligent approaches to ensuring the verification of safety rules in an automated and time-saving way multiply the capitalization of the project, the possibilities of safety planning and detection of hazards (Bachurina et al, 2015; Churbanov et al, 2018; Gambatese et al, 2005; Hartmann et al, 2020).

\section{Results}

As a result of the analytical study, it was revealed that BIM technologies offer completely new opportunities for planning a construction site and visualizing information. A BIM-based construction master plan (CMP) is like a snapshot of a construction site at a specific point in time. Of course, additional models of site planning are needed, given the continuity of changes in site configurations at different stages of construction. The ultimate goal is to be in sync with these dynamic changes using 4D site models in the future. An important application of BIM to ensure safety when planning a construction site can be the modeling of formwork equipment and technological cycles during the construction process, namely, viewing plans based on BIM in order to obtain a general understanding of the management organization, timely identification of the results of safety checks, as well as information about the product and quantity. In total, six different tests were carried out within the framework of one project, the results of which are shown in Table l (International Labour OYce ,1985; J.P. Zhang et al, 2011; Kazaryan, 2020;Kiviniemi et al, 2012).

The first test showed that the planning of a construction master plan, which is based on 2D planning, does not allow designing and taking into account all factors. Therefore, does not meet the needs of the designers. The site layout model should not be static or twodimensional, but dynamic, encapsulating the entire 3D site. For example, BIM can be used to assemble a tower crane for planning lifting and safety checks during construction. 3D modeling will allow checking the reach and ability of a tower crane during the construction and installation works (CIW). In addition, it becomes possible to analyze the risks 
REVISTA DE LA UNIVERSIDAD DEL ZULIA. $3^{a}$ época. Año $13 \mathrm{~N}^{\circ}$ 36, 2022

Elen Bilonda Tregubova \& Ruben Kazaryan /// Assessment of the efficiency of using information... 305-322 DOI: http://dx.doi.org/10.46925//rdluz.36.20

associated with an arrow crash or a fall of a load (Khoshnava et al, 2012; Korabelnikova et al, 2019; Lu Y.,et al, 2021; Kazaryan, 2019). The importance of this expertise becomes obvious when the space around the construction site is limited and collisions are possible (Fig. 2).

Table 1. Tests for the study and demonstration of BIM technologies in planning and management of construction safety

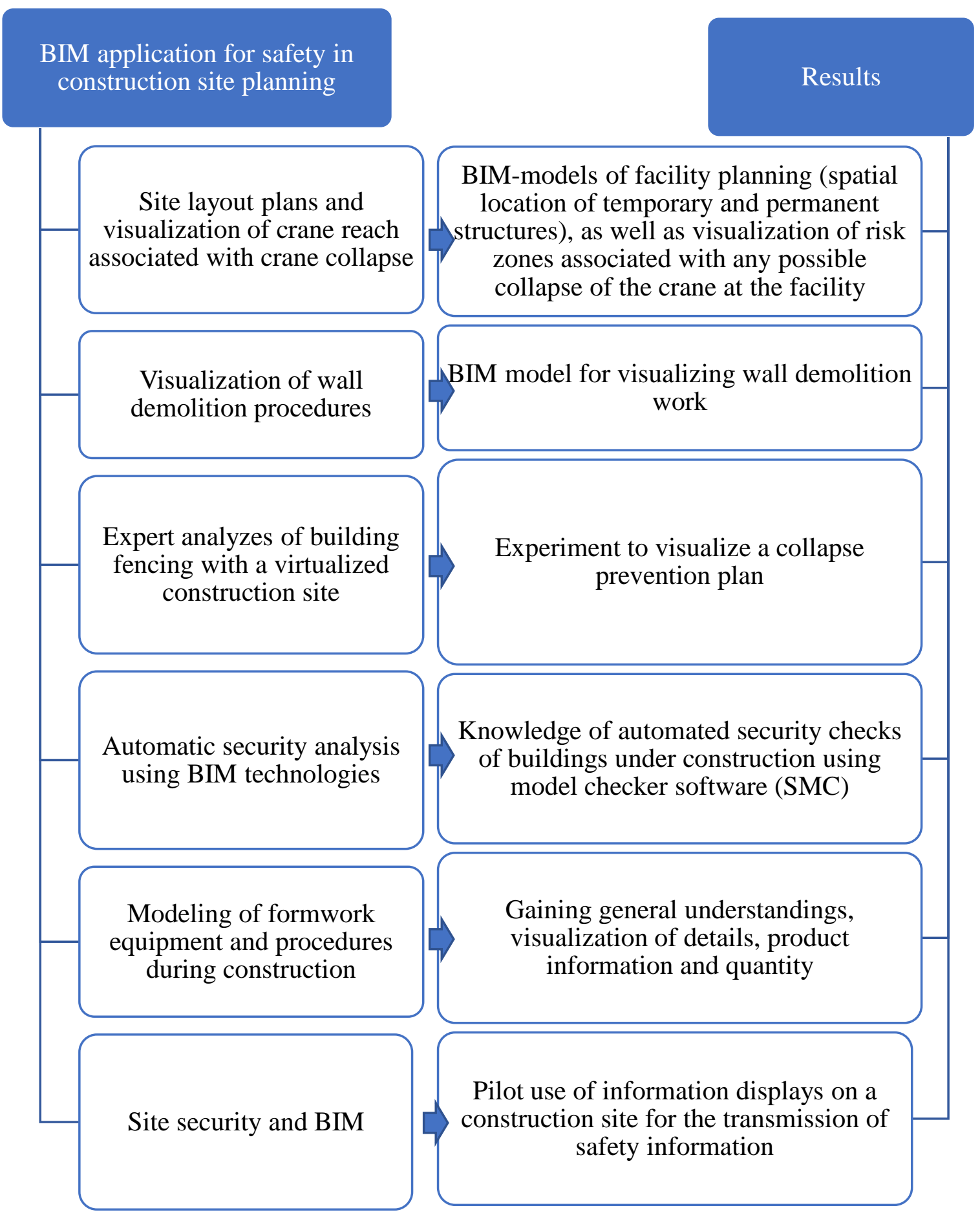




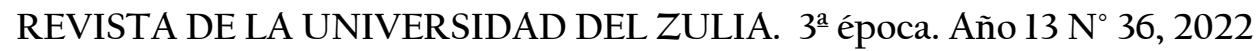

Elen Bilonda Tregubova \& Ruben Kazaryan /// Assessment of the efficiency of using information... 305-322 DOI: http://dx.doi.org/10.46925//rdluz.36.20

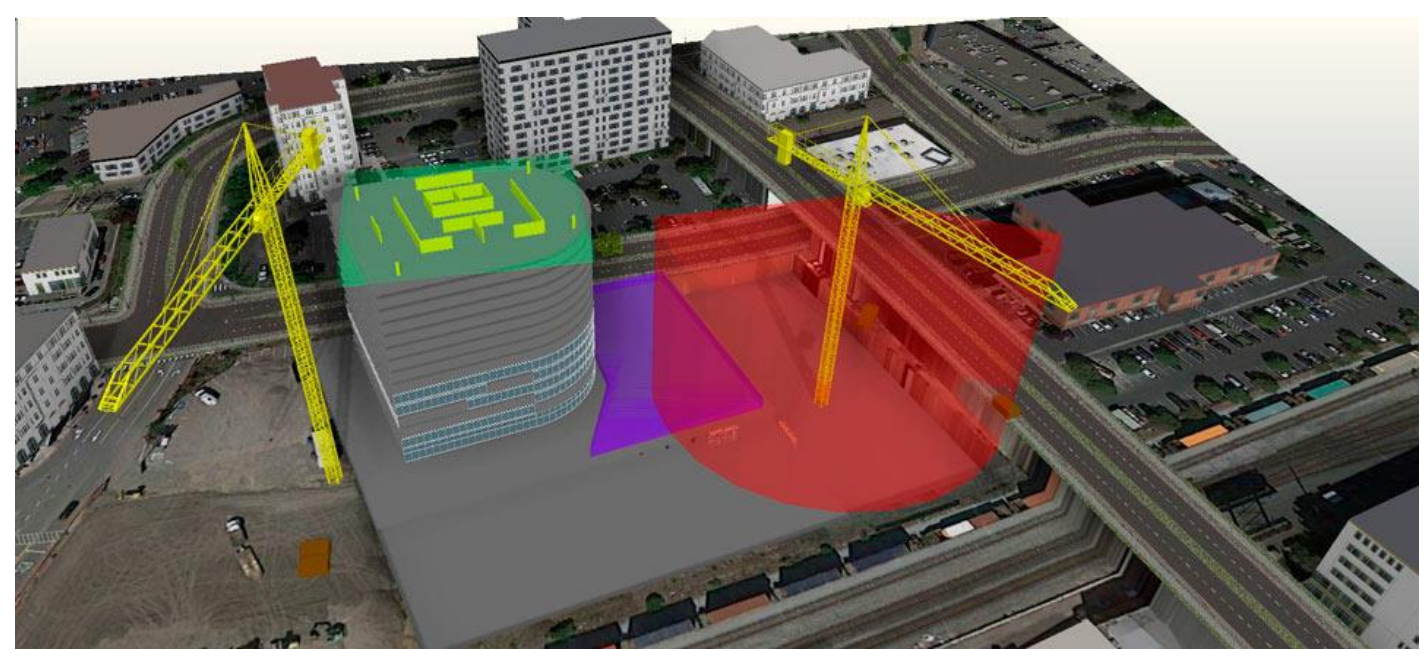

Figure 2. Crane reach visualization

It is also possible to clearly assess the difference in visualization between a 3D plan developed using information technology and a common 2D master plan (Fig. 3).
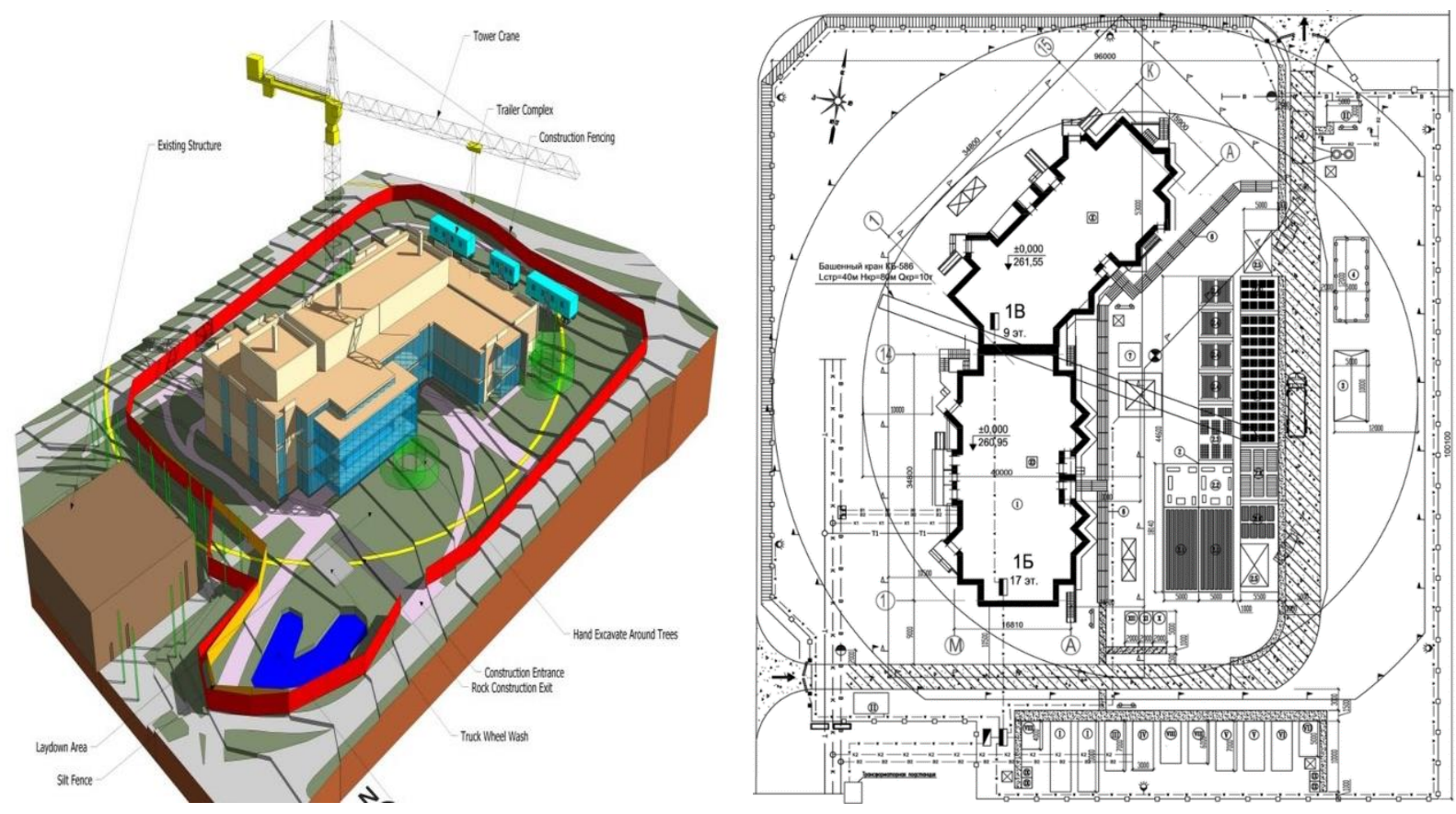

Figure 3. Comparison of visualization of 3D and 2D design of a master plan

In tests for the demolition (dismantling) of walls, BIM technologies provide a clear color scheme of the technological sequence, providing a comfortable digitalization of the element base of the control quality system in comparison with 2D drawings. Automatic safety analysis allows assessing how the project meets the safety requirements using the model checker software (SMC) (Khoshnava et al, 2012; Korabelnikova et al, 2019; Lu Y.,et al, 
REVISTA DE LA UNIVERSIDAD DEL ZULIA. $3^{a}$ época. Año $13 \mathrm{~N}^{\circ}$ 36, 2022

Elen Bilonda Tregubova \& Ruben Kazaryan /// Assessment of the efficiency of using information... 305-322 DOI: $\underline{\text { http://dx.doi.org/10.46925//rdluz.36.20 }}$

2021; Kazaryan, 2019; Kazaryan, 2020). The considered method makes it possible to identify inconsistencies in the created interconnections of the object's processes, approaching the solution of the problem systematically at the organizational and technological level. This model allows identifying space-time collisions at the level of management decisions and design solutions. Thus, risks are minimized at the planning stage and in the process of operation, including facilities that are technically complex and especially dangerous (Fig. 4).

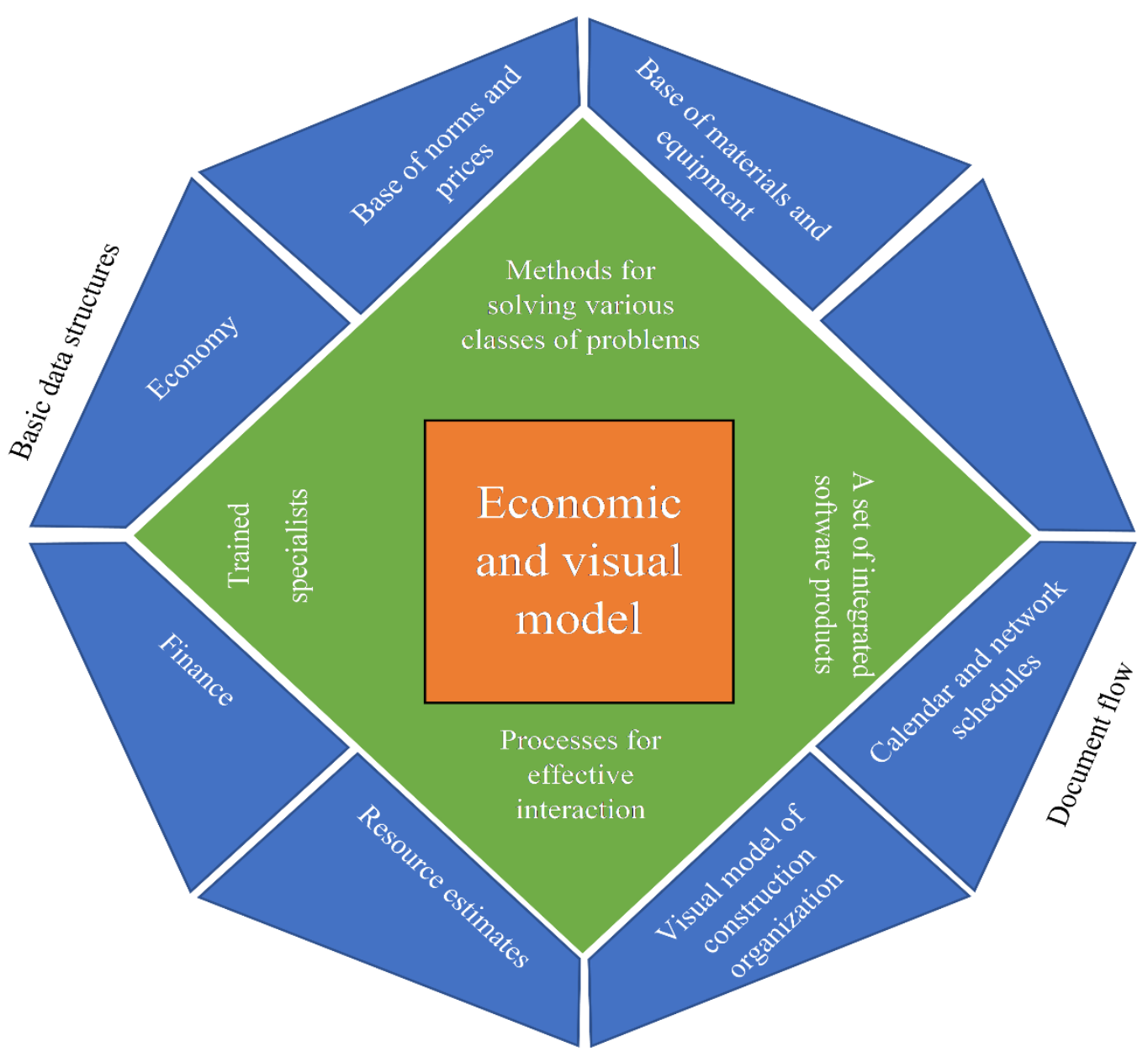

Figure 4. Schematic diagram of the economic and visual model

3. Discussion

The main task of the EVM is formed as follows (the algorithm in the diagram 1): $\operatorname{pref}(D, C)\{E, S, Q=\mathrm{const}\}>f(b, v, i, j, d, m, p, r, a, t, w)$, 
REVISTA DE LA UNIVERSIDAD DEL ZULIA. $3^{a}$ época. Año $13 \mathrm{~N}^{\circ}$ 36, 2022

Elen Bilonda Tregubova \& Ruben Kazaryan /// Assessment of the efficiency of using information... 305-322 DOI: http://dx.doi.org/10.46925//rdluz.36.20

where:

- Basic parameters of the construction project:

$\checkmark \quad$ D - the total planned duration of the construction of the facility from the beginning of the development of working documentation to the handing over of the facility to the balance of the Developer;

$\checkmark \quad C$ - the total planned cost of the construction of the facility from the beginning of the development of working documentation to the handing over of the facility to the balance of the Developer;

- Main limitations of the construction project:

$\checkmark \quad$ E-planned operational characteristics of the facility under construction;

$\checkmark \quad S$-safety requirements for the facility under construction;

$\checkmark \quad$ Q- quality requirements for the facility under construction;

- Variables:

$\checkmark \quad$ b-number and composition of temporary buildings and structures;

$\checkmark \quad \mathrm{v}$ - cost of work according to current standards and statistics;

$\checkmark \quad \mathrm{i}$ - the number and composition of interfaces between the main participants in the construction project;

$\checkmark \quad \mathrm{j}$-number of operations related to intrasite logistics;

$\checkmark \quad$ d-number of operations related to supply logistics;

$\checkmark \quad \mathrm{m}$ - number of construction equipment;

$\checkmark \quad \mathrm{p}$-the number and composition of operations at the construction base;

$\checkmark \quad \mathrm{r}$-number of labor resources;

$\checkmark \quad$ a-number of spatial collisions;

$\checkmark \quad \mathrm{t}$-number of spatio-temporal and temporal collisions;

$\checkmark \quad$ W-cost of raising financial resources.

Handling the formalities of a construction project begins with the study of an investment feasibility study, in other words, the discovery of the usefulness and feasibility of erecting a specific building on a specific territory. In the technical part, the conditions for the planned operational features of the building being constructed (E), the quality requirements for the constructed object (Q), and the requirements for its safety (S) are substantiated. The requirements approved in the terms of reference for the construction object remain 
REVISTA DE LA UNIVERSIDAD DEL ZULIA. $3^{a}$ época. Año $13 \mathrm{~N}^{\circ}$ 36, 2022

Elen Bilonda Tregubova \& Ruben Kazaryan /// Assessment of the efficiency of using information... 305-322 DOI: http://dx.doi.org/10.46925//rdluz.36.20 unchanged in the future during the further development of the design documentation. These requirements can only be changed by the developer, if the general contractor makes the corresponding decision. Within the economic part of the investment substantiation, IRR, NPV and ROI estimates are made (shown in Scheme 1).

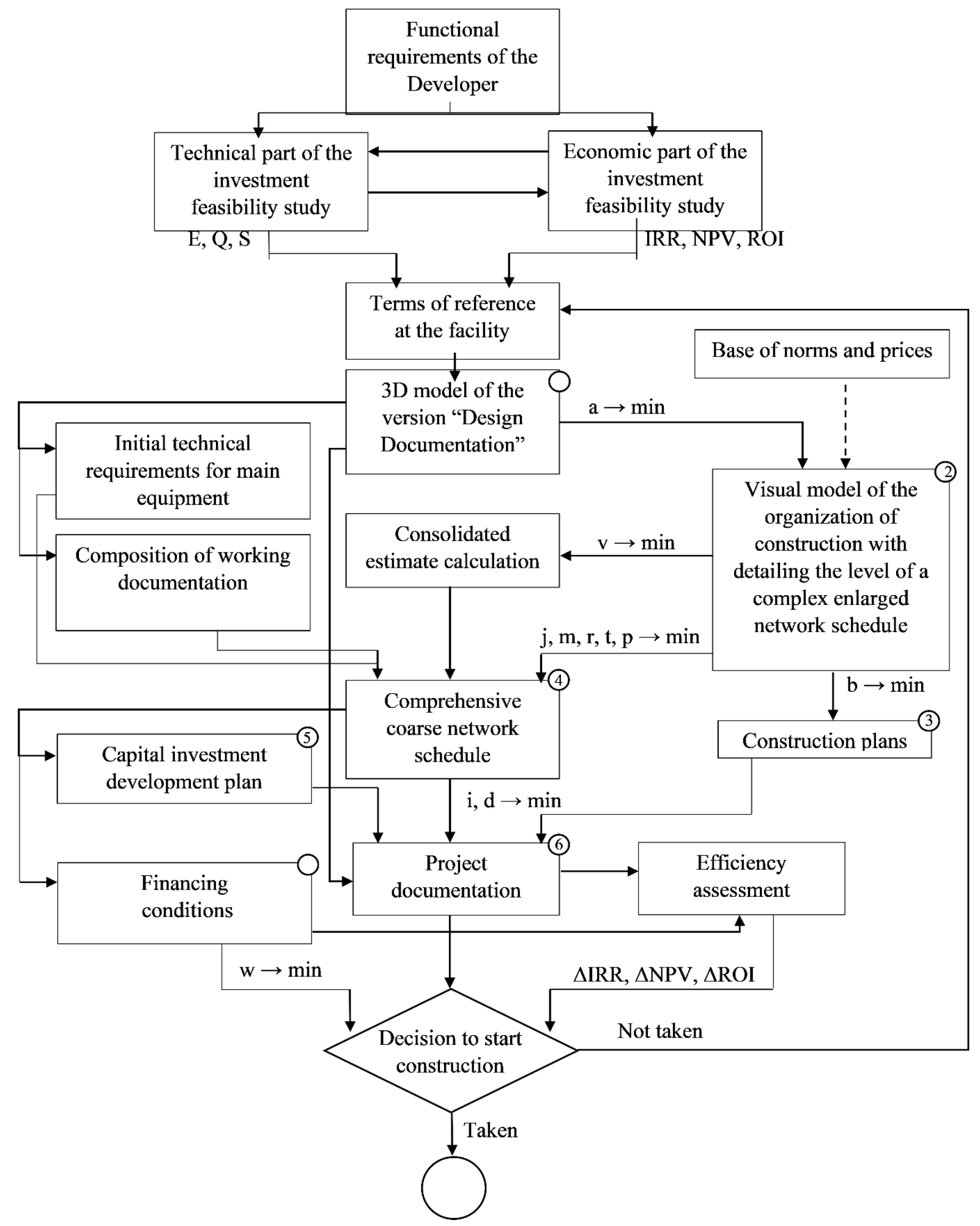

Scheme 1. Algorithm of EVM functioning 
REVISTA DE LA UNIVERSIDAD DEL ZULIA. $3^{a}$ época. Año $13 \mathrm{~N}^{\circ}$ 36, 2022

Elen Bilonda Tregubova \& Ruben Kazaryan /// Assessment of the efficiency of using information... 305-322 DOI: http://dx.doi.org/10.46925//rdluz.36.20

A typical process for developing a COP, taking into account the requirements provided for by SNiP 3.01.01-85 for the development of a COP and (or) WPP for industrial facilities, for the development of projects for organizing construction work for industrial facilities using the nodal method, as well as departmental building codes for the development of a COP (electric power industry) consists of the stages that are shown in Scheme 2. In order to determine the efficiency of using this method in further studies, it is planned to consider an algorithm based on calculating the difference in the cost of organizational and technological solutions before and after using an EVM, which, in accordance with scientific the technical hypothesis of the authors, will provide a reduction in the cost of key performance indicators and organizational and technological solutions incorporated in the original construction organization project. The algorithm for determining the efficiency of using an EVM for the purpose of developing a COP is considered in Scheme 3. A detailed study will be considered at the facilities using atomic energy, created within the framework of the federal target program "Nuclear Energy Technologies of a New Generation".

\begin{tabular}{|l|}
\hline First stage: \\
- \\
- \\
obtaining and studying the design assignment; \\
development of a construction organization project; \\
- familiarization with construction conditions.
\end{tabular}

Scheme 2. Stages of development of a construction organization project 
REVISTA DE LA UNIVERSIDAD DEL ZULIA. $3^{a}$ época. Año $13 \mathrm{~N}^{\circ}$ 36, 2022

Elen Bilonda Tregubova \& Ruben Kazaryan /// Assessment of the efficiency of using information... 305-322

DOI: http://dx.doi.org/10.46925//rdluz.36.20

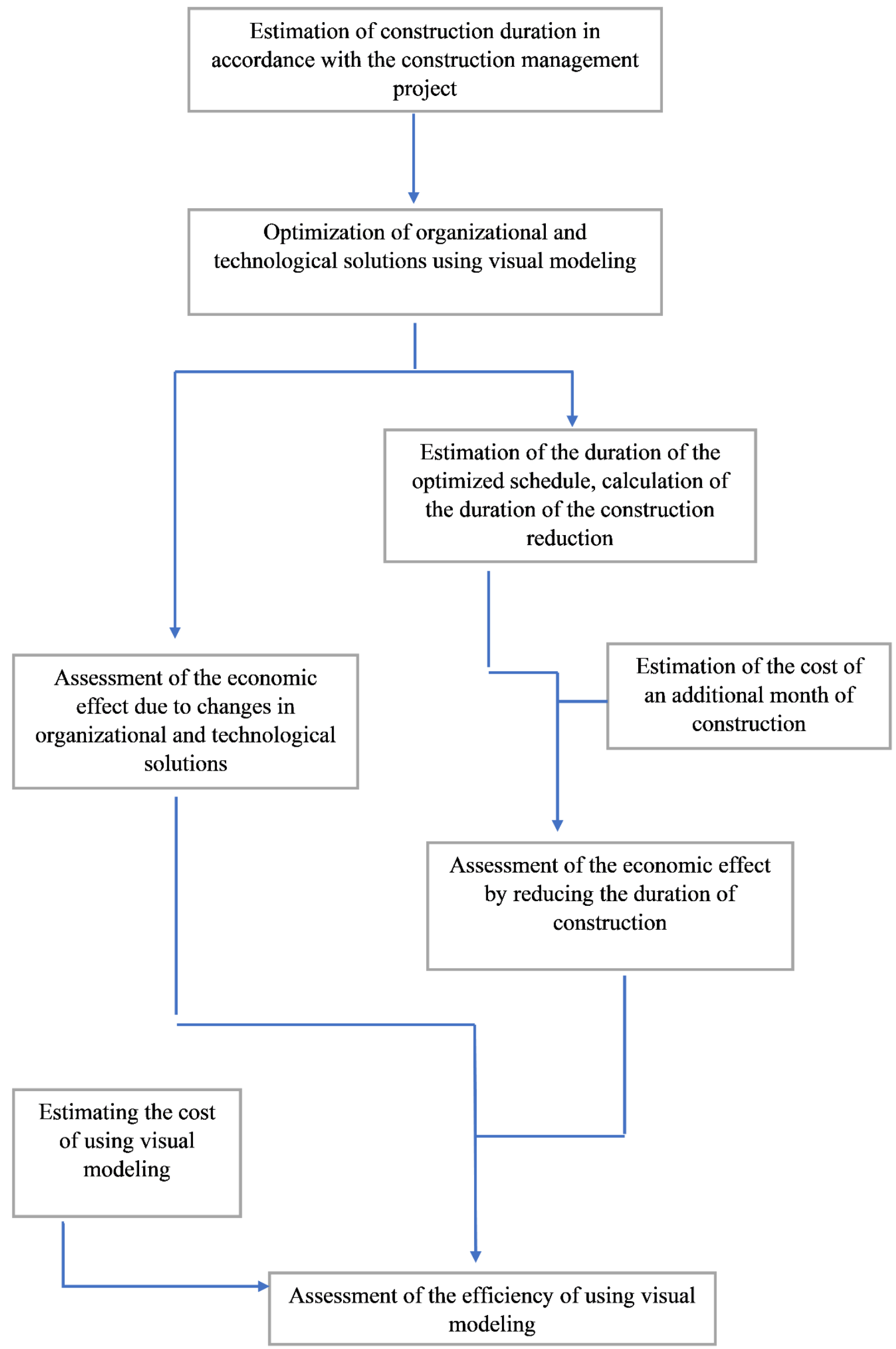

Scheme 3. Algorithm for assessing the economic efficiency of using EVM of a COP 
REVISTA DE LA UNIVERSIDAD DEL ZULIA. $3^{a}$ época. Año $13 \mathrm{~N}^{\circ}$ 36, 2022

Elen Bilonda Tregubova \& Ruben Kazaryan /// Assessment of the efficiency of using information... 305-322

DOI: http://dx.doi.org/10.46925//rdluz.36.20

Security monitoring using 4D modeling opens up completely new possibilities for the analysis and assessment of safety in the framework of construction work. BIM technologies can also be used in training and education on worker safety, safety engineering, safety planning (analysis of work hazards and pre-planning of tasks), accident investigation, as well as at the stage of ensuring the safety of facilities and maintenance (Khoshnava et al, 2012; Korabelnikova et al, 2019; Lu Y.,et al, 2021; Kazaryan, 2019; Kazaryan, 2020; Kazaryan, 2021; Sijie Zhang et al, 2015; Sudakov et al, 2013; Sulankivi, 2014; Sultanova, 2015; Chulkov et al, 2020).

\section{Conclusions}

Planning of a construction master plan using BIM technologies proves to be a useful tool and versatile visualization solution for ensuring the safety of various projects. The preparation of such an information model of a construction site requires appropriate professional competencies and thinking that provide a high-quality production plan for a construction site compared to traditional approaches that do not allow careful study of all the necessary activities due to the huge amount of information on one plane sheet. Safety planning can be part of the 4D planning production process, which will provide an opportunity to shape safety planning practices, detailing elements of different levels of planning and management. The full implementation of information modeling technologies in the practice of construction production is hampered by the lack of funding sources in the structure of the consolidated estimate calculation in order to introduce and apply such innovative technologies, which is a constraining factor in the implementation of investment and construction projects that are carried out at the expense of the state budget. As a result, an appropriate funding basis should be provided in the structure of the consolidated estimate calculation as part of the work on revising the provisions on the composition of sections of project documentation and requirements for their content.

The introduction of economic and visual modeling (EVM) in the development of a project for the production of work will provide a solution to the initial requirements associated with the tasks of finding an optimal solution for the cost of a building being erected on the basis of architectural, structural, engineering, economic, financial, resource, organizational and technological characteristics (Adnan Enshassi et al, 2016; Aleksandrova 
REVISTA DE LA UNIVERSIDAD DEL ZULIA. $3^{a}$ época. Año $13 \mathrm{~N}^{\circ}$ 36, 2022

Elen Bilonda Tregubova \& Ruben Kazaryan /// Assessment of the efficiency of using information... 305-322 DOI: http://dx.doi.org/10.46925//rdluz.36.20

et al, 2018; B. Akinci et al, 2002; Bachurina et al, 2015; Churbanov et al, 2018; Gambatese et al, 2005; Hartmann et al, 2007; Hiravennavar et al, 2020; International Labour 1985; J.P. Zhang et al, 2011; Kazaryan, 2020; Kiviniemi et al, 2011; Kazaryan, 2020; Kazaryan, 2019; Kazaryan, 2021; Sijie Zhang et al, 2015; Sudakov et al, 2013; Sulankivi,2014; Sultanova , 2015; Chulkov et al, 2020; Vitaliy et al, 2020).

\section{References}

Adnan Enshassi, Abed Ayyash \& Rafiq M. Choudhry (2016). BIM for construction safety improvement in Gaza strip: awareness, applications and barriers, International Journal of Construction Management, 16:3, 249-265. DOI:10.1080/15623599.2016.1167367

Aleksandrova E. B. (2018). Minimizing the risks of investment and construction projects using BIM technologies // "Innovations and Investments", No. 1l, (2018), pp. 15 - 18

Akinci, B.; Fischer, M.; Levitt, R.; Carlson, R. (2002). Formalization and automation of timespace conflict analysis, Journal of Computing in Civil Engineering 16 (2) (2002), 124-134. DOI:10.1061/(ASCE)0887-3801(2002)16:2(124)

Bachurina S.S., Sultanova I.P. (2015). The concept of creating an economic and visual model of a tool for increasing the efficiency of the implementation of investment and construction projects // Theory of urban planning. (2015). No. 1. P. 11-14.

Churbanov A.E., Shamara Yu.A. (2018). The influence of information modeling technology on the development of the investment and construction process. Vestnik MGSU. (2018).Vol. 13. Issue 7 (118). P. 824 - 835. DOI:10.22227/1997-0935.2018.7.824-835

Chulkov, V.O.; Kazaryan, R.R. (2019). The Concept of Advance Formation of Anthropotechnical Security of Functioning and Life Quality of a Human in Cyberphysical Building Systems Using Digitalization, Modern Management Trends and the Digital Economy: from Regional Development to Global Economic Growth" (MTDE 2020), Advances in Economics, Business and Manangment Research, volume 138, pp 371-376. DOI:10.2991/iscde-19.2019.124

Downey, Jennifer (2012). Turner Innovation Series - BIM Conference Istanbul. Construction Company.

Gambatese, J., Behm, M., Hinze., J. (2005) Viability of Designing for Construction Worker Safety, Journal of Construction Engineering and Management, 131 (9), 1029-1036. DOI:10.1061/(ASCE)0733-9364(2005)131:9(1029)

Hartmann, T and Fischer, M (2007) Supporting the constructability review with 3D/4D models. "Building Research and Information", 35(1), 70-80. DOI:10.1080/09613210600942218

Hiravennavar, Apurva \& Angadi, Shivamanth (2020). Implementation construction site safety plan using bim model // 49th ASC Annual International Conference Proceedings. 
REVISTA DE LA UNIVERSIDAD DEL ZULIA. $3^{a}$ época. Año $13 \mathrm{~N}^{\circ}$ 36, 2022

Elen Bilonda Tregubova \& Ruben Kazaryan /// Assessment of the efficiency of using information... 305-322

DOI: http://dx.doi.org/10.46925//rdluz.36.20

International Labour OYce (ILO) (1985). Safety and health in building and civil engineering work. International Labour OYce, Geneva.

Kazaryan, Ruben (2020). The Problem of a Rational Relationship of the General Transport Infrastructure, Proceedings of the XIII International Scientific Conference on Architecture and Construction (2020), LNCE 130, 2021, pp.33-39. DOI:10.1007/978-981-33-6208-6 4

Kazaryan, Ruben (2019). Aspects in Managing the Life Cycle of Construction Projects, Part (SPRINGER) of the Advances in Intelligent Systems and Computing book series (AISC, volume 1258). EMMFT (2019), pp 768-776. DOI:10.1007/978-3-030-57450-5 65

Kazaryan, Ruben (2020). Bases of Elements of Multi-Criteria Analysis of Quality of Design Decisions, WMCAUS 2020; IOP Publishing IOP Conf. Series: Materials Science and Engineering; doi:10.1088/1757-899X/960/2/022036 960 (2020), 022036.

Kazaryan, Ruben (2020). Some Aspects of Anthropotechnical Safety Management Concept, WMCAUS 2020; IOP Publishing IOP Conf. Series: Materials Science and Engineering; doi:10.1088/1757-899X/960/2/022036 960 (2020), 022037.

Kazaryan, Ruben (2019). The Concept of Anthropotechnical Safety of Functioning and Quality of Life, Part (SPRINGER) of the Advances in Intelligent Systems and Computing book series (AISC, volume 1258). EMMFT 2019, pp 759-767. DOI:10.1007/978-3030-57450-5 64

Kazaryan, Ruben (2021). The Concept of Development of the Integrated Transport System of the Russian Federation, Transportation Research ProcediaVolume 54, (2021), pp 602-609.

Kiviniemi, M., Sulankivi, K., Kähkönen, K., Mäkelä, T., \& Merivirta, M-L. (2011). BIM-based Safety Management and Communication for Building Construction. VTT Technical Research Centre of Finland. VTT Tiedotteita - Research Notes No. 2597 http://www.vtt.fi/inf/pdf/tiedotteet/2011/T2597.pdf

Korabelnikova S.S., Korabelnikov S.K. Digital technology as an element of reducing the risks in the construction. Diskussiya [Discussion], 93, 18 - 27. DOI 10.24411/2077-7639-2019-10002

Korabelnikova S.S., Korabelnikov S.K. Digital technology as an element of reducing the risks in the construction. Diskussiya [Discussion], 93, 18 - 27

Lu Y., Gong P., Tang Y., Sun S., Li Q. BIM-integrated construction safety risk assessment at the design stage of building projects Automation in Construction, Volume 124, (2021)

Sijie Zhang, Kristiina Sulankivi, Markku Kiviniemi, Ilkka Romo, Charles M. Eastman, Jochen Teizer, BIM-based fall hazard identification and prevention in construction safety planning // Safety Science, Volume 72, (2015), Pages 31-45, ISSN 0925-7535, https://doi.org/10.1016/j.ssci.2014.08.001.

Sudakov, K.V., Chulcov, V.O., Kazaryan, R.R., Glazachev, O.S., Dmitrieva, N.V., Komarov, N.M., (2013). Antropotechnics: Norm in every living thing and artificial beings. SvR-ARGUS, Moscow. 
REVISTA DE LA UNIVERSIDAD DEL ZULIA. $3^{a}$ época. Año $13 \mathrm{~N}^{\circ}$ 36, 2022

Elen Bilonda Tregubova \& Ruben Kazaryan /// Assessment of the efficiency of using information... 305-322 DOI: $\underline{\text { http://dx.doi.org/10.46925//rdluz.36.20 }}$

Sulankivi, K. (2014). BIM promoting construction site safety: Industry examples. Paper presented at Using BIM to Enhance Construction Safety and Health.

Sultanova I.P. Analysis of planning, management, and development of organizational and technological solutions in major construction projects // Vestnik MGSU. (2015). No. 7. P. 127136. DOI:10.22227/1997-0935.2015.7.127-136

Vitaliy O. Chulkov, Ruben R. Kazaryan, Anastasya I. Shatrova (2020). Innovative water proofing of exploitable roofs in high-rise construction, Journal of Mechanics of Vontinua and Mathematical Sciences, Special Issue, No-8, April, (2020), pp 144-154.

Zhang, J.P.; Hu, Z.Z. (2011). BIM- and 4D-based integrated solution of analysis and management for conflicts and structural safety problems during construction: 1. Principles and methodologies, Automation in Construction, Volume 20, Issue 2, (2011), Pages 155-166, ISSN 0926-5805, https://doi.org/10.1016/j.autcon.2010.09.013. 